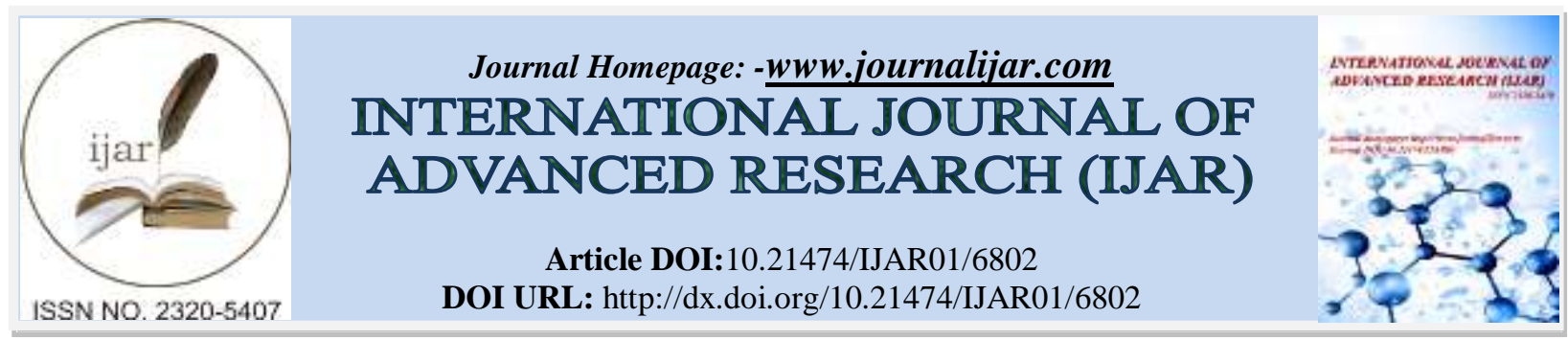

RESEARCH ARTICLE

\title{
A STUDY ON THE USE OF E-BANKING FACILITIES BY THE SMALL RETAILERS OF TINSUKIA TOWN.
}

1. Associate Professor, CMS, Dibrugarh University.

\section{Dr. Pratim Barua and Karuna Goenka.}

2. Assistant Professor, Women's College, Tinsukia; Research Scholar, Dibrugarh University.

\section{Manuscript Info}

Manuscript History

Received: 21 January 2018

Final Accepted: 23 February 2018

Published: March 2018

\begin{abstract}
Small retailers contribute towards the economy of a country to a great extent. They may not generate as much money as large corporations, but they are a major contributor of and a critical component of local economies. They increase employment opportunities thereby decreasing the unemployment rate, rate of poverty. They employ those people too who may not be employable by the bigger organizations. Creation of employment has multi-fold effect on the economy. The more prominent effects being decreasing poverty, creating wealth, circulating the flow of money in the economy, etc. Thus, it becomes a matter of utmost importance to study whether the small retailers are also shifting to a technology based system of transacting. The success of shifting to a cashless economy can only be ensured if the small retailers also adopt the various cashless techniques available. This study is based upon primary data whereby Schedule method has been adopted to collect data from various retailers of Tinsukia Town and inferences have been drawn from the data so collected with the help of descriptive statistics.
\end{abstract}

Copy Right, IJAR, 2018,. All rights reserved.

\section{Introduction:-}

Retail markets and shops have a very ancient history, dating back to antiquity. Over the centuries, retail shops were transformed from small stores to the sophisticated shopping malls that we know today.

Retailing is the process of selling consumer goods or services to customers to earn a profit. Retailers satisfy demand identified through a supply chain. Some of the earliest retailers were itinerant peddlers. Retailers purchase goods from the wholesalers and make it available to the ultimate consumer or the end user in small packs. Retailers also maintain variety of the products so as to cater to the consumer demands in the best possible way. Creation of Time utility and Place utility are core purposes of a retail business. A retailer is the last but one of the most important link in the distribution chain. Retailers come in direct contact with the consumers and serve as a link between the manufacturer and the consumer. Acting as a perfect middleperson, a retailer is responsible for delivering the customer with their requirement by forwarding the consumer demand to the company. Retailers may be large, medium or small. Small retailers are those who have not yet transformed themselves into the modern types of retailing such as large departmental stores, chain stores, etc. They still exist as sole proprietors or HUFs or partnership firms; operating in a particular area. They are in true sense the conventional traders. 
Modern retailers are involved in making a variety of strategic level decisions including the type of store, the market to be served, the optimal product assortment, customer service, supporting services and the store's overall market positioning. Once the strategic retail plan is in place, retailers devise the retail mix which includes product, price, place, promotion, personnel and presentation. In the digital age, an increasing number of retailers are seeking to reach broader markets by selling through multiple channels, including both the conventional shops and online retailing. Digital technologies are also changing the way that consumers pay for goods and services. Retailing support services may also include the provision of credit, delivery services, advisory services, stylist services and a range of other supporting services.

\section{Significance of the Study:-}

The dream of transforming India into a cashless economy can only be achieved if its implementation is ensured at all levels. The comfort of common men will determine the success of automation of the day to day transactions, which is of utmost importance when we talk about cashless economy. Thus, a need to study the frequency and quantum of use of e-banking services by the small retailers is significant.

\section{Objectives of the Study:-}

1. To study whether the small retailers are using the e-banking services in their normal business operations.

2. To determine the success of e-banking among small retailers.

\section{Research Methodology:- \\ Nature of the Study:-}

The study is empirical in nature.

\section{Scope of the Study:-}

The study has been done in Tinsukia Town. Although, the policies of various banks don't differ much from place to place, yet, any generalizations should be made cautiously.

\section{Sampling Method:-}

Cluster Sampling Method has been used to carry out the research. The retailers were divided into clusters based upon the location of their shops. The clusters formed for the research are as follows:

1. G.N.B. Road West

2. G.N.B. Road East

3. Chirwapatty \& Parbotia

4. Development

5. Rangagora Road

6. A.T. Road

7. Makum Road

8. Hijuguri

$50 \%$ of the total no. of clusters i.e. 4 Out of the 8 clusters identified, were selected with the help of Lottery Method. The total numbers of retailers were 1480 .

\section{Sample Size:-}

The sample consisted of the following four clusters which consisted of 820 retailers:

1. G.N.B. Road West

2. Hijuguri

3. Development

4. Makum Road.

\section{Data Collection Method:-}

The study is based purely on primary data. Thus, primary data for the study has been collected with the help of schedules so as to overcome the problem of language or literacy status.

\section{Data Analysis \& Interpretation:-}

The data collected has been analyzed with the help of descriptive statistics and conclusions have been drawn thereupon. 


\section{Findings \&Recommendations:-}

An in-depth study led to identification of various lacunas which need to be rectified. The study revealed the following:

1. Most of the respondents do not possess high educational qualifications. It can be clearly seen that only $39 \%$ of the respondents possess a graduation degree.

2. The respondents have been into their respective businesses since a very long period of time. Most (88\%) of the business establishments have been operating for more than 25 years.

3. Most i.e. $77 \%$ of the respondents are only using as well as providing Cash as the sole medium of transacting due to high charges imposed by banks on Point of Sale (PoS) Machines.

4. Few which accounts for $23 \%$ are using both Cash/Card for their business transactions but however, refrain from using the cards due to the same problem of imposing charges upon PoS Machines.

5. There are no respondents who only use card as a method of transacting.

Based upon the various findings, the adoption of the following suggestions may be considered:

1. Abolition of charges for using e-banking facilities.

2. Introduction of incentives by banks to promote e-banking.

\section{Conclusion:-}

Inclusive growth should be aimed at when we talk about economic growth. The study identified the main concern relating to additional charges imposed by banks for using e-banking facilities. This is proving to be a hindrance in the mission of making a digital India. Thus, emphasis needs to be laid upon efforts to make a common man technically literate. E-banking should ease business transactions rather than becoming an additional cost center. If, Small Retailers start using e-banking in their day to day business then the dream of a Digital India can soon be turned into reality. 